\title{
Implementation of an improvement cycle in the care of a primary health care
}

\author{
Implantação de um ciclo de melhoria no acolhimento de uma unidade básica de saúde \\ Implantación de un ciclo de mejora en la acogida de una unidad básica de salud
}

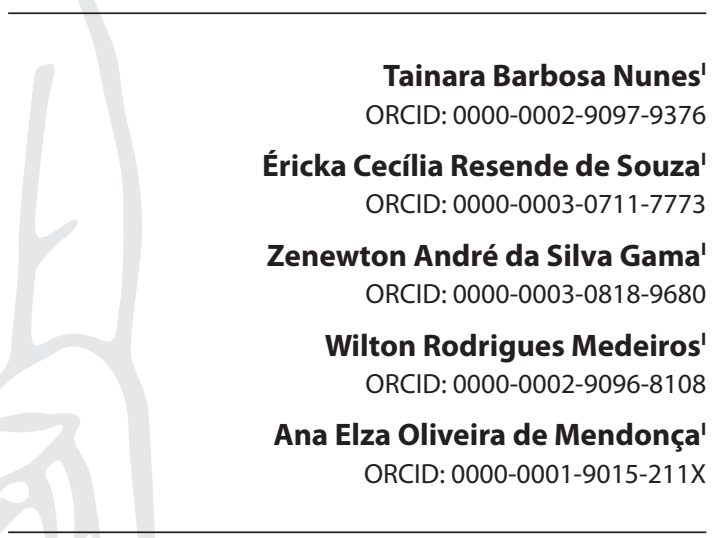

'Universidade Federal do Rio Grande do Norte. Natal, Rio Grande do Norte, Brazil.

How to cite this article:

Nunes TB, Souza ECR, Gama ZAS, Medeiros WR, Mendonça AEO. Implementation of an improvement cycle in the care of a primary health care. Rev Bras Enferm. 2021;74(1):e20200099. doi: http://dx.doi.org/10.1590/0034-7167-2020-0099

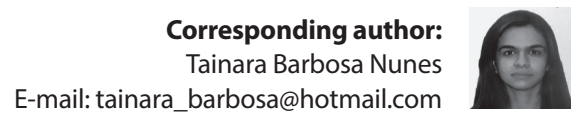

EDITOR IN CHIEF: Antonio José de Almeida Filho ASSOCIATE EDITOR: Hugo Fernandes

Submission: 04-19-2020

Approval: 09-17-2020

\begin{abstract}
Objectives: to evaluate the effectiveness of a quality improvement cycle applied to the care of spontaneous demand in a primary care center. Methods: quasi-experimental before and after study, with a quantitative approach and no control group. An improvement cycle was carried out in a primary care center in the city of Guarabira/PB using five quality criteria. An evaluation, an intervention focused on the most problematic criterion and a reassessment were carried out. The samples were random $(n=60)$. The percentages and confidence intervals of compliance with each criterion were verified. Statistical significance was calculated using the $Z$ test. Results: after the intervention, there was a significant improvement in two quality criteria of the care of spontaneous demand users (the user must be heard by a professional and go through the risk classification). Conclusions: the improvement cycle was an effective quality management method.
\end{abstract}

Descriptors: User Embracement; Primary Health Care; Health Services Research; Community Participation; Total Quality Management.

\section{RESUMO}

Objetivos: avaliar a efetividade de um ciclo de melhoria aplicado ao acolhimento à demanda espontânea em uma unidade básica de saúde. Métodos: estudo quase experimental, do tipo antes e depois, sem grupo controle e com abordagem quantitativa. Realizou-se um ciclo de melhoria em uma unidade básica de saúde no município de Guarabira/PB, utilizando cinco critérios de qualidade. Foram realizadas uma avaliação, uma intervenção focada no critério mais problemático e uma reavaliação. As amostras foram aleatórias ( $\mathrm{n}=$ $60)$, sendo verificados os percentuais e intervalos de confiança do cumprimento de cada critério, assim como o cálculo da significância estatística, através do teste Z. Resultados: após a intervenção realizada, houve melhoria significativa em dois critérios de qualidade do acolhimento à demanda espontânea (o usuário ser ouvido por algum profissional e passar pela classificação de risco). Conclusões: a realização do ciclo de melhoria se mostrou efetiva como método de gestão da qualidade.

Descritores: Acolhimento; Atenção Primária à Saúde; Avaliação de Serviços de Saúde; Centros de Saúde; Melhoria de Qualidade.

\section{RESUMEN}

Objetivos: evaluar la eficacia de un ciclo de mejora aplicado a la acogida de demanda espontánea en una unidad básica de salud. Métodos: se trata de un estudio casi experimental, del tipo antes y después, sin grupo control y con enfoque cuantitativo. Se llevó a cabo un ciclo de mejoras en una unidad básica de salud de la ciudad de Guarabira, estado de Paraíba, Brasil, en el que se utilizaron cinco criterios de calidad. Se realizó una evaluación, una intervención centrada en los criterios más problemáticos y una reevaluación. Las muestras fueron aleatorias $(n=60)$ y se comprobaron los porcentajes e intervalos de confianza del cumplimiento de cada criterio, así como el cálculo de la significación estadística, utilizando el test Z. Resultados: después de la intervención, se produjo una mejora significativa en dos criterios de calidad de la acogida de demanda espontánea (el usuario es escuchado por algún profesional y pasa por la clasificación de riesgo). Conclusiones: la realización del ciclo de mejora se mostró eficaz como método de gestión de la calidad.

Descriptores: Acogida; Atención Primaria de la Salud; Investigación sobre Servicios de Salud; Centros de Salud; Mejora de la Calidad. 


\section{INTRODUCTION}

Improving the quality of health services is a global need, and investment in Primary Health Care (PHC) is a fundamental principle for achieving success in this endeavor ${ }^{(1)}$. In Brazil, PHC or Primary Care (PC) is considered the first step of health care and the preferred gateway to the Unified Health System (SUS), and Family Health is the priority strategy for the expansion and consolidation of $\mathrm{PC}^{(2)}$. However, despite the recent expansion of $\mathrm{PC}$ in Brazil, there are many challenges for the provision of quality service in this level of health care.

Aiming to tackle these challenges, the Ministry of Health (MS) has implemented, in 2011, the National Program to Improve Access and Quality of Primary Care (PMAQ-AB), which is a guideline for changing the conditions and modes of operation of Primary Care Center (PCCs), aiming to improve the assistance and care provided to the population ${ }^{(3)}$.

One of the key processes valued in the PMAQ to improve the quality of PC services is adequate care of users and of their health needs, even when they spontaneously seek the health service. The Instructions Manual of the PMAQ includes care of spontaneous demand as an essential standard for all PCCs, as it is related to the minimum conditions of access and quality that must be offered by the team ${ }^{(4)}$. Therefore, user care is a way of collaborating with the qualification of health systems, facilitating access to fair and comprehensive care ${ }^{(5)}$.

User care is also one of the main guidelines of the National Humanization Policy $(\mathrm{PNH})^{(6)}$ and is considered a lightweight technology that optimizes user demands and organizes the care process in health services, through bonding relationships and attentive and qualified listening, with the user as the main factor and an active participant ${ }^{(2)}$. Qualified listening aims to recognize the health demands and needs of the user, promoting adequate access based on the assessment of vulnerabilities and risks ${ }^{(7)}$. Studies reveal that user care has been fragmented, restricted to occasional consultations and associated with limited access and attention centered on complaint-conduct ${ }^{(8-9)}$. Also, it has been revealed that users are dissatisfied when they do not feel welcomed and heard by the team ${ }^{(10)}$.

A survey carried out with 1,313 users and 324 teams showed that the professionals most involved in user care were community health workers, followed by nurses ${ }^{(11)}$. However, the Family Health Strategy (FHS) teams are multidisciplinary and care is a responsibility of all professionals ${ }^{(12)}$. In this sense, it is important to strengthen the understanding of the role of each professional of the PCC in the care of users, so that a quality access can be provided through the collaboration of different categories in the care of spontaneous demand users.

Therefore, it is necessary to have new approaches and/or strategies for the systematization of user care, with the objective of improving the quality of services and user satisfaction. It can be said that the weaknesses pointed out in the literature reveal the need for studies on the improvement of user care in PC. Addressing these weaknesses is challenging and, for that, methods of continuous improvement of the quality of care in the context of PCCs are recommended (1).

Given the above, this study is based on the implementation of an improvement cycle, which consists of the identification problem in quality in a given service, with the objective of solving or improving it through predefined steps ${ }^{(13)}$. For this purpose, user care was considered in three contexts: as a mechanism for expanding/facilitating access, as posture, attitude and care technology and as a device for (re)organizing the teamwork process ${ }^{(6)}$.

\section{OBJECTIVES}

To evaluate the effectiveness of a quality improvement cycle applied to the care of spontaneous demand in a primary care center.

\section{METHODS}

\section{Ethical aspects}

The study followed the ethical recommendations of Resolution 466/12 of the National Health Council, and was submitted to the Research Ethics Committee of the Federal University of Rio Grande do Norte. The participants were informed about the objectives of the study and were asked to sign the Informed Consent Form (ICF) ${ }^{(14)}$.

\section{Study design, period and study setting}

This is a quasi-experimental before and after study, with a quantitative approach and no control group. It was carried out through the application of a quality improvement cycle, following the guidelines of the Standards for Quality Improvement Reporting Excellence 2.0 (SQUIRE). This instrument establishes standards for the publication of experiences in improvement cycle projects ${ }^{(14-15)}$.

The study was carried out in a PCC in the city of Guarabira/ Paraíba (PB), from January to July 2018. The population of the center consists of 3,060 users and a team initially composed of 13 professionals. The physical structure of the PCC is composed of an entrance hall, a screening/procedures room, a vaccination room and the medical, nursing and dental offices; there is no room for user care.

There is an average of 900 individual visits per month in this PCC; among these, 50\% are medical consultations, 38.9\% are nursing consultations and $22.2 \%$ are dental consultations; $41 \%$ of these visits are spontaneous, $32 \%$ are scheduled and $27 \%$ are programmed/continued care ${ }^{(14)}$.

\section{Sample size; inclusion and exclusion criteria}

The improvement cycle requires a manageable sample size to guarantee the feasibility of the study. A sample of 60 cases is recommended, but it is also possible to make evaluations with smaller samples, respecting the minimum of 30 cases $^{(13-14)}$. In this study, a sample of 60 cases was used in each evaluation.

The target population of the study were all users who sought care at the PCC without prior appointment, which is called spontaneous demand. Users over eighteen years old participated in data collection and those with any limitations that made it difficult to understand the questions of the research instrument were excluded. 


\section{Study protocol}

The steps followed to implement the improvement cycle were: 1- identification and prioritization of the problem in quality, 2- analysis of the causes of the problem, 3- development of the quality criteria, 4- initial evaluation of compliance with the criteria, 5- improvement intervention, 6- re-evaluation to verify the effectiveness of the intervention performed ${ }^{(14)}$.

Steps one, two, three and five were participatory, involving the PCC team composed of thirteen people: a receptionist, six community health workers, a doctor, a nurse, two nursing technicians, a dentist and an oral health assistant.

\section{Identification and prioritization of the problem in quality}

The problem in quality was identified at a team meeting. A prioritization matrix was used. For this technique, the existing in the work process of the PCC were listed and "care of spontaneous demand" was considered a priority, obtaining the highest score according to the following criteria used for evaluation: 1 . Does it affect many patients? 2. Does it represent a serious health risk? 3. Does the possible solution depend on internal efforts? 4. Is it a cheap solution (13-14). $^{\text {. }}$

\section{Analysis of the causes of the problem}

The method chosen for the analysis of the problem was the flowchart (Figure 1), through which it was possible to visualize the stages and activities of the user care process, allowing the identification of failures and critical components ${ }^{(14)}$.

The care of all users by a single PCC employee was considered one of the critical components, especially in the first hours of business, when there is a greater flow of people. Another aspect highlighted was the provision of qualified listening to spontaneous demand users and the offer of care or guidance compatible with the health needs presented ${ }^{(14)}$.

\section{Development of the quality criteria}

After analyzing the problem, the quality criteria related to the care of spontaneous demand were defined (Chart 1). These criteria were established according to the proposals of the $\mathrm{PNH}$, the Primary Care Notebooks for Care of Spontaneous Demand and the PMAQ, and were considered valid and reliable ${ }^{(14)}$.

The criteria are considered effective parameters to measure the quality of a service and correspond to the desired objectives, that is, the goal of excellence. Therefore, they must be important, realistic and accepted by all professionals involved in the objective $^{(13-14)}$.

\section{Initial evaluation and re-evaluation of compliance with the criteria (steps 4 and 6)}

The evaluations of this improvement cycle were carried out through the application of a questionnaire with spontaneous demand users. The questionnaire addressed the pre-established quality criteria (Chart 1) in dichotomous questions that verified if the criteria were being met. Thus, in the present study, 60 cases were evaluated for each criterion, through the participation of 120 users. Data collection was carried out by two community health workers shortly after the end of the users' service at the center.

The evaluations occurred in two moments, before and after the improvement intervention, the first in January and the second in July 2018. The six months period between one evaluation and another was when the improvement intervention was implemented $^{(14)}$.

\section{Improvement intervention}

An intervention plan was elaborated considering the data from the first evaluation, prioritizing actions directed to the criteria with the lowest compliance. For this, a structured method of participatory planning was used with the team's professionals.

The tool used was the affinity diagram, which is a group process for generating ideas to solve a proposed problem, which are then ordered in strategic lines of activities to be carried out. The diagram was applied during one of the PCC planning meetings that occur monthly. The ideas were grouped into three main groups of actions (Chart 2)(14).

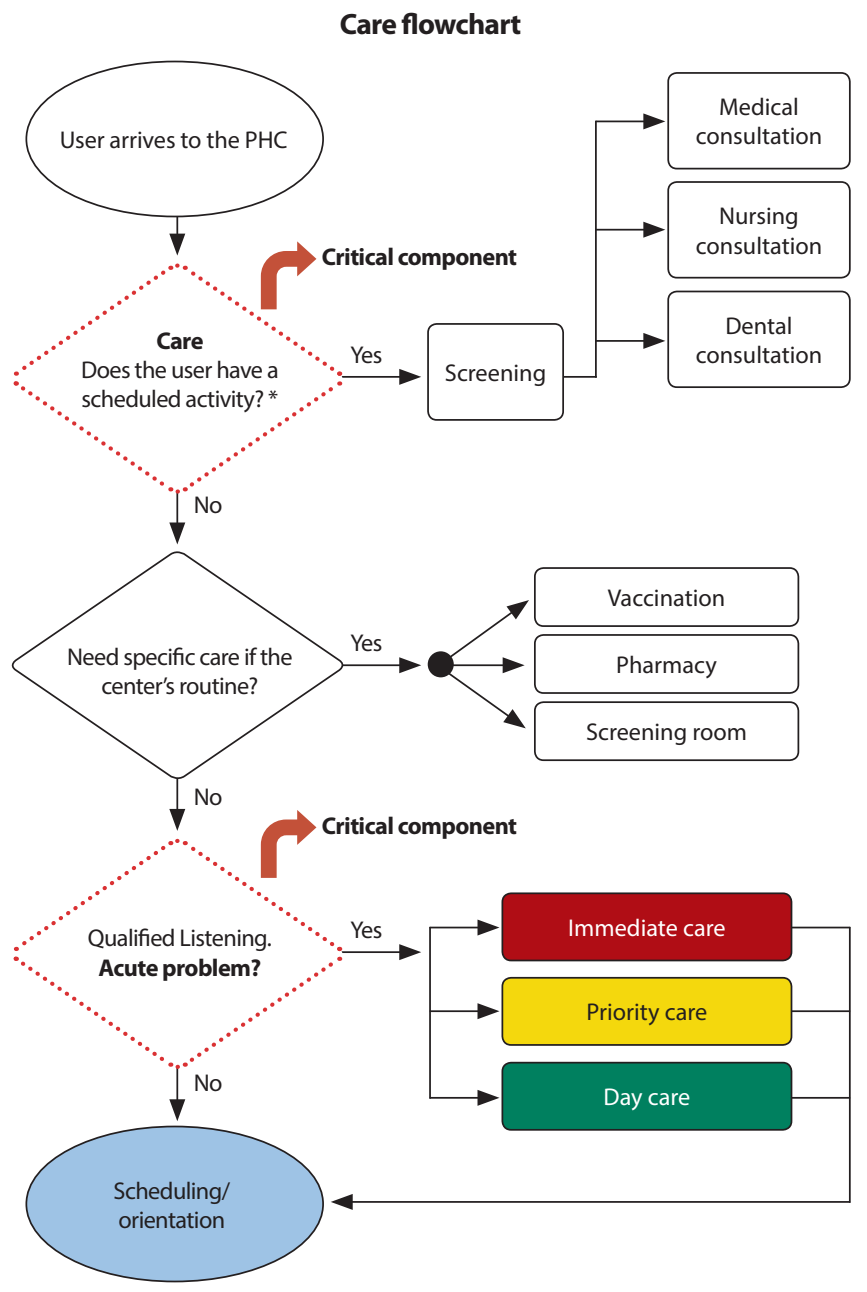

Note: PCC - Primary Care Center.

Figure 1 - Care flowchart, Guarabira, Paraíba, Brazil, 2018 
Chart 1 - Quality criteria for the care of spontaneous demand, Guarabira, Paraíba, Brazil, 2018

\begin{tabular}{|c|c|c|}
\hline Criteria & Exception & Clarifications \\
\hline $\begin{array}{l}\text { 1. All spontaneous demand users must be heard by a } \\
\text { professional of the center. }\end{array}$ & None & $\begin{array}{l}\text { Spontaneous demand users are those who seek the PCC } \\
\text { without prior appointment, regardless of the reason. }\end{array}$ \\
\hline $\begin{array}{l}\text { 2. All spontaneous demand users with clinical } \\
\text { complaints must be classified according to risk and } \\
\text { vulnerability in immediate, priority or day care and be } \\
\text { informed about their classification. }\end{array}$ & None & $\begin{array}{l}\text { Classifications: } \\
\text { Immediate care is one that involves life threat and needs } \\
\text { immediate intervention; } \\
\text { Priority care is one that involves moderate risk; } \\
\text { Day care is one that involves low risk or no risk with important } \\
\text { vulnerability, and that needs to be managed on the same day. }\end{array}$ \\
\hline $\begin{array}{l}\text { 3. All spontaneous demand users without clinical (acute) } \\
\text { complaints who are referred to appointment scheduling } \\
\text { must wait a maximum of } 15 \text { days to the consultation. }\end{array}$ & None & The appointment can be scheduled with a doctor or nurse. \\
\hline $\begin{array}{l}\text { 4. All users who need procedures performed at the PCC } \\
\text { must be assisted in the same shift. }\end{array}$ & $\begin{array}{l}\text { When the procedure is not } \\
\text { performed due to lack of } \\
\text { material/supplies at the PCC }\end{array}$ & $\begin{array}{l}\text { Procedures performed at the PCC: measurement of blood } \\
\text { pressure, capillary blood glucose, dressings, vaccination, } \\
\text { nebulization, removal of stitches and application of injectables. }\end{array}$ \\
\hline 5. All users must leave the center satisfied with the care. & None & $\begin{array}{l}\text { A satisfied user is one whose expectations regarding the } \\
\text { care were met. }\end{array}$ \\
\hline
\end{tabular}

Note: PCC - Primary Care Center.

Chart 2 - Affinity diagram: What can be done to improve the care of spontaneous demand?, Guarabira, Paraíba, Brazil, 2018

\begin{tabular}{|c|c|}
\hline \multicolumn{2}{|r|}{ O WHAT SHOULD WE DO TO IMPROVE THE CARE OF SPONTANEOUS DEMAND? } \\
\hline $\begin{array}{l}\text { Organization of } \\
\text { the work process }\end{array}$ & $\begin{array}{l}\text { - Provide a vest to identify the professional who is collaborating in the care } \\
\text { - Create a schedule of professionals for care } \\
\text { - Systematize risk classification } \\
\text { - Handle assistance forms identified by colors according to the risk classification } \\
\text { - Adapt the management of the schedule of doctors and nurses according to the availability for day and urgent consultations }\end{array}$ \\
\hline $\begin{array}{l}\text { Training of the } \\
\text { team }\end{array}$ & $\begin{array}{l}\text { - } \quad \text { Create study groups on care } \\
\text { - } \text { Have a period of training in care } \\
\text { - } \text { Reassess the practice at monthly meetings }\end{array}$ \\
\hline $\begin{array}{l}\text { Orientations to } \\
\text { the users of the } \\
\text { PCC }\end{array}$ & $\begin{array}{l}\text { - Display the center's assistance flowchart } \\
\text { - Conduct a waiting room group discussion to explain the work process of the center } \\
\text { - Define a time limit to arrive to scheduled appointments. }\end{array}$ \\
\hline
\end{tabular}

\section{Analysis of results and statistics}

The data collected in the two evaluations were analyzed by calculating the percentage of compliance with the quality criteria, using a $95 \%$ confidence interval. To estimate the improvement between initial assessment and reevaluation, absolute and relative improvements for each of the criteria were calculated $^{(13-14)}$. To test the statistical significance of the improvement detected, a one-tailed hypothesis test was performed by calculating the value of $Z$, considering the absence of improvement as a null hypothesis, which was rejected when $\mathrm{p}$-value was lower than $0.05^{(14)}$.

\section{RESULTS}

Table 1 shows that all criteria had a high percentage of compliance in the initial evaluation, except for criterion 2, which refers to risk classification. Therefore, this was the most problematic criterion, and it was prioritized while planning the actions of the improvement intervention.

After the implementation of the intervention, criterion 2 (risk classification of users) had an absolute improvement of $40 \%$ and criterion 1 (all spontaneous demand users must be heard by a professional of the center) showed an absolute improvement of $5 \%$. Both the criteria presented a p-value of less than 0.05 , characterizing a statistically significant improvement ${ }^{(14)}$.
Table 1 - Level of quality before and after the intervention and statistical significance of the improvement: comparison of results of the $1^{\text {st }}$ and $2^{\text {nd }}$ evaluation, Guarabira, Paraíba, Brazil, 2018

\begin{tabular}{|c|c|c|c|c|c|}
\hline & \multicolumn{2}{|c|}{$1^{\text {st }}$ evaluation $2^{\text {nd }}$ evaluation } & \multirow{2}{*}{$\begin{array}{l}\text { Absolute } \\
\text { improvement }\end{array}$} & \multirow{2}{*}{$\begin{array}{c}\text { Relative } \\
\text { improvement }\end{array}$} & \multirow{2}{*}{$\begin{array}{l}\text { Statistical } \\
\text { significance }\end{array}$} \\
\hline & $\mathrm{N}=60$ & $N=60$ & & & \\
\hline Criteria & p1 (IC 95\%) & p2 (IC 95\%) & p2-p1 & $\begin{array}{l}\mathrm{p} 2-\mathrm{p} 1 \\
100-\mathrm{p} 1\end{array}$ & $p$ value \\
\hline 1 & $95 \%( \pm 5 \%)$ & $100 \%( \pm 0 \%)$ & $5 \%$ & $1 \%$ & 0.040 \\
\hline 2 & $30 \%( \pm 12 \%)$ & $70 \%( \pm 11 \%)$ & $40 \%$ & $57 \%$ & $<0.001$ \\
\hline 3 & $100 \%( \pm 0 \%)$ & $18.3 \%( \pm 10 \%)$ & $-81.7 \%$ & $-81.7 \%$ & NA \\
\hline 4 & $100 \%( \pm 0 \%)$ & $100 \%( \pm 0 \%)$ & $0 \%$ & $0 \%$ & NA \\
\hline 5 & $100 \%( \pm 0 \%)$ & $100 \%( \pm 0 \%)$ & $0 \%$ & $0 \%$ & NA \\
\hline
\end{tabular}

Note: $p 1$ - percentage of compliance in the first evaluation; $p 2$-percentage of compliance in the second evaluation; NA - The hypothesis test does not apply, as there was no absolute improvement.

1-All spontaneous demand users must be heard by a professional of the center;

2- All spontaneous demand user with clinical complaints must be classified according to risk and vulnerability in immediate, priority or day care and be informed about their classification: 3-All spontaneous demand users without clinical (acute) complaints who are referred to appointment scheduling must wait a maximum of 15 days to the consultation;

4- All users who need procedures performed at the PCC must be assisted in the same shift; 5-All users must leave the center satisfied with the care.

The percentage of compliance with criterium 4 (all users who need procedures performed at the PCC must be assisted in the same shift) and 5 (all users must leave the center satisfied with the care) was not altered in both evaluations, remaining with the maximum level of compliance (100\%). However, there was a decrease in criterion 3 (all spontaneous demand users without clinical (acute) complaints who are referred to appointment scheduling must wait a maximum of 15 days to the consultation) 
from $100 \%$ compliance to $18.3 \%$. It is worth noting that in the first evaluation, the PCC team was complete, but in the second evaluation the center had been without a doctor for four months, which increased the demand for care from nurses and consequently increased the time between scheduling and care ${ }^{(14)}$.

\section{DISCUSSION}

The results obtained in this improvement cycle demonstrated that the intervention implemented by PCC professionals was effective in improving the criteria that had a lower compliance in the initial evaluation. It also stimulated self-assessment in the center's team, promoting positive changes in the work process and increasing the understanding of shared responsibilities. The evaluations show that hearing spontaneous demand users has been consolidated as a team practice. Studies reveal that hearing complaints without no need to make an appointment contributes to user satisfaction regarding the care received ${ }^{(13,16-17)}$, showing that satisfaction is more associated with humane care than with structural and functioning conditions of the health center ${ }^{(14)}$.

The implementation of risk classification as an improvement intervention is in line with the efforts of the PNH to qualify care. It is a way of giving a new meaning to the screening process, as it usually ends in the entrance hall and does not include an analysis of the risks and vulnerabilities of the users. This stage can be an opportunity for a humane relationship, providing means for comprehensive, continuous, and safe care ${ }^{(18)}$. An explicit care provides transparency to the use of resources involved in the provision of care ${ }^{(19)}$.

However, studies ${ }^{(20-22)}$ have found that users feel dissatisfied when they are not seen immediately by a doctor and consider the risk classification as a barrier to access and an unnecessary step. Therefore, the use of this tool in primary care requires constant analysis, assessing positive and negative points that can influence the user's perception of access ${ }^{(18)}$.

The worsening of waiting time between scheduling and consultation was related to the absence of a doctor in the team, which was pointed out in a study ${ }^{(22-23)}$ as one of the reasons for dissatisfaction in care. This fact reflects the Brazilian reality of scarcity and poor distribution of these professionals, and the difficulty of city managers in attracting and keeping doctors in family health teams ${ }^{(18)}$. This difficulty was one of the reasons for the creation of the government program Mais Médicos in July 2013, with the objective of tackling problems in the development of primary care in the country.

The long wait for consultations in the PCC is frequently reported as a reason for dissatisfaction of users ${ }^{(10)}$. Users feel that this waiting time infringes on their right to access healthcare ${ }^{(24)}$. According to a study ${ }^{(25)}$, the users' perception of the quality of primary care improves when they have access to care more quickly.

In this study, it was not possible to identify a direct association between user satisfaction and the improvement in the risk classification or the worsening in the waiting time between the appointment and the consultation, as it remained unchanged in the second evaluation. One aspect that may be related to user satisfaction in the present study is the recognition and appreciation of the center's multidisciplinary team, as there was already a bond and trust relationship between the users and the team, which, at the time of the evaluation, had already been in this workplace for three years ${ }^{(14)}$. It is known that employee turnover impairs the establishment of a bond and weakens user care ${ }^{(26)}$.

However, studies assessing user satisfaction often do not reveal exactly how people are being treated in the health system, since the perception of users involves subjective aspects and expectations regarding care. These factors can make it difficult to measure user satisfaction ${ }^{(20)}$. In addition, studies on satisfaction present temporary results; a continuous assessment is essential, as it allows monitoring the performance of organizations according to the quality criteria ${ }^{(27)}$.

Based on the results of this improvement cycle, it was observed that it is important to include the participation of users in the stages of problem analysis and intervention planning when involving the topic of satisfaction, as the user's view is extremely important to direct the planning of actions that meet their needs. Thus, the evaluation of the quality of the health service is important for monitoring improvement actions over time ${ }^{(28)}$.

\section{Limitations of the study}

A limitation of this study was that it was conducted in a single PCC. Therefore, it is necessary to replicate this study in other centers so that the findings can be compared with these results. However, this does not reduce the relevance of this study.

\section{Contributions to the area of health}

The study was important to measure the effects of actions related to user care in primary care, which resulted from the planning and implementation of interventions to improve the assistance to SUS users.

\section{CONCLUSIONS}

The improvement cycle was effective as a quality management method in this health service. It enabled the analysis of the causes of the problem, with the objective of designing an intervention to improve it. Through this, it was possible to achieve a significant improvement in the criteria of hearing and risk classification. It is essential to continue the cycle to assess the need for planning new interventions.

It is expected that the method used in the present study will be disseminated for use in different problems or opportunities for improvement in PC, so that it can contribute to its strengthening and have a positive impact on the lives of users.

\section{REFERENCES}

1. World Health Organization (WHO). International Bank for Reconstruction and Development. The World Bank. Delivering quality health services: a global imperative for universal health coverage[Internet]. Geneva: World Health Organization; 2018 [cited 2019 Aug 12]. Available from: https://apps.who.int/iris/bitstream/handle/10665/272465/9789241513906-eng.pdf 
2. Ministério da Saúde (BR). Gabinete do Ministro. Portaria no. 2.436 de 21 de setembro de 2017. Aprova a Política Nacional de Atenção Básica, estabelecendo a revisão de diretrizes para a organização da Atenção Básica, no âmbito do Sistema Único de Saúde (SUS) [Internet]. Diário Oficial da União, Brasília, DF, 22 set, 2017 [cited 2019 Aug 12]. Available from: http://bvsms.saude.gov.br/bvs/saudelegis/gm/2017/prt2436_22_09_2017.html

3. Ministério da Saúde (BR). Gabinete do Ministro. Portaria no 1.645, de 2 de outubro de 2015. Dispõe sobre o Programa Nacional de Melhoria do Acesso e da Qualidade da Atenção Básica (PMAQ-AB) [Internet]. Diário oficial da União, Brasília, DF, 5 out, 2015 [cited 2019 Aug 12]. Available from: http://bvsms.saude.gov.br/bvs/saudelegis/gm/2015/prt1645_01_10_2015.html

4. Ministério da Saúde (BR). Manual Instrutivo para as equipes de atenção básica e NASF [Internet]. Brasília; 2017 [cited 2019 Aug 12]. Available from: http://189.28.128.100/dab/docs/portaldab/documentos/Manual_Instrutivo_3_Ciclo_PMAQ.pdf

5. Coutinho LRP, Barbieri AR, Santos MLM. Reception in Primary Health Care: an integrative review. Saúde Debate. 2015;39(105):514-24. doi: $10.1590 / 0103-110420151050002018$

6. Ministério da Saúde (BR). Secretaria de Atenção à Saúde. Departamento de Atenção Básica. Acolhimento à demanda espontânea. Brasília: Ministério da Saúde; 2013.

7. Ministério da Saúde (BR). Política Nacional de Humanização: PNH [Internet]. Brasília, DF; 2013 [2017 Aug 15]. Available from: http://bvsms. saude.gov.br/bvs/publicacoes/politica_nacional_humanizacao_pnh_folheto.pdf

8. Nilson LG, Maeyama MA, Kaminagakura FG, Souza TC, Dolny LL. User embracement in the perception of medical students. Rev APS. 2018;21(1):6-20. doi: 10.34019/1809-8363.2018.v21.15893

9. Costa PCP, Garcia APRF, Toledo VP. Welcoming and nursing care: a phenomenological study. Texto Contexto Enferm. 2016;25(1):e4550015. doi: 10.1590/0104-07072016004550014

10. Gomide MFS, Pinto IC, Bulgarelli AF, Santos ALP, Serrano GMP. User satisfaction with primary health care: an analysis of access and care. Interface (Botucatu). 2018;22(65):387-398. doi: 10.1590/1807-57622016.0633

11. Almeida PF, Marin J, Casotti E. Strategies for the consolidation of the coordination of care by primary care. Trab Educ Saúde. 2017;15(2):373398. doi: 10.1590/1981-7746-sol00064

12. Silva ACS, Soares IRB, Campos KFC, Castro MCS. A Atenção Primária sob a ótica dos usuários do Sistema Único de Saúde: uma revisão bibliográfica. Rev Sustinere. 2019;7(1):46-72. doi: 10.12957/sustinere.2019.36184

13. Saturno PJ, Antón JJ, Santiago MC. La construcción de criterios para evaluar la calidad. Manual del Máster en Gestión de la Calidad en los Servicios de Salud. Módulo 3. Universidad de Murcia; 2008.

14. Nunes TB. Avaliação do acolhimento à demanda espontânea em uma unidade básica de saúde e intervenções para melhoria[Dissertação]. Universidade Federal do Rio Grande do Norte, Natal, 2018. 50f.

15. Taylor MJ, Mcnicholas C, Nicolay C. Systematic review of the application of the plan-do-study-act method to improve quality in healthcare. BMJ Qual Saf [Internet]. 2014 [cited 2019 Feb 17];23(4):290-8. Available from: https://qualitysafety.bmj.com/content/23/4/290

16. Menezes ELC, Scherer MDA, Verdi MI, Pires DP. Manners of producing care and universality of access in primary health care. Saude Soc. 2017;26(4):888-903. doi: 10.1590/s0104-12902017170497

17. Protasio APL, Gomes LB, Machado LS, Valença AMG. User satisfaction of primary health care by Brazilian regions: 1 st cycle of the external evaluation PMAQ-AB. Ciênc Saúde Coletiva [Internet]. 2017 [cited 2018 Jun 22];22(6):1829-44. doi: 10.1590/1413-81232017226.26472015

18. Moreira DA, Tibães HB, Batista RCR, Cardoso CML, Brito MJM. Manchester triage system in primary health care: ambiguities and challenges related to access. Texto Contexto Enferm [Internet]. 2017 [cited 2019 Jan 10];26(2). doi: 10.1590/0104-07072017005970015

19. Rossato K, Real VR, Oliveira GB, Araujo CDC. Reception with risk rating in the family health strategy: perception of the nursing team. Rev Enferm UFSM[Internet]. 2018[cited 2019 Jun 20];8(1):144-156. doi: 10.5902/2179769226655

20. Arruda CAM, Bosi MLM. Satisfação de usuários da atenção primária à saúde: um estudo qualitativo no Nordeste do Brasil. Interface (Botucatu). 2017;21(61):321-32. doi:10.1590/1807-57622015.0479

21. Baraldi DC, Souto BGA. A demanda do Acolhimento em uma Unidade de Saúde da Família em São Carlos, São Paulo. Arq Bras Ciências Saúde [Internet]. 2011 [cited 2020 Jan 15];36(1):10-7. Available from: https://www.portalnepas.org.br/abcs/article/view/69

22. Nonnenmacher CL, Weiller TH, Oliveira SG. Healthcare clients' opinions regarding the embracement including risk classification. Rev Eletron Enferm [Internet]. 2012 [cited 2019 Dec 10];14(3):541-9. Available from: https://revistas.ufg.br/fen/article/view/13462/13376

23. Oliveira DC, Cecilio HPM, Gomes AMT, Marques SC, Spindola T, Pontes APM. The universalization and access to health: consensus and disagreement between professionals and users. Cad Saúde Colet. 2017;25(4):483-490. doi: 10.1590/1414-462×201700040078

24. Quevedo ALA, Rossoni E, Pilotto LM, Pedroso MRO, Pacheco PM. Direito à saúde, acesso e integralidade: análise a partir de uma unidade saúde da família. Rev APS [Internet]. 2016 [cited 2018 Jun 28];19(1):47-57. Available from: https://lume.ufrgs.br/handle/10183/168757

25. Vidal TB, Rocha SA, Harzheim E, Hauser L, Tesser CD. Scheduling models and primary health care quality: a multilevel and cross-sectional study. Rev Saúde Pública [Internet]. 2019 [cited 2020 Apr 18];53:38. doi: 10.11606/s1518-8787.2019053000940

26. Tonelli B, Leal AP, Tonelli W, Veloso DC, Gonçalves D, Tonelli S. Personnel turnover of the Family Health Strategy in Montes Claros, Minas Gerais, Brazil. RFO UFP [Internet]. 2018 [cited 18 Apr 2020];23(2):180-5. doi: 10.5335/rfo.v23i2.8314

27. Fontana KC, Lacerda JT, Machado PMO. Work Process in Primary Health Care: evaluation of management. Saúde Debate [Internet]. 2016 [cited 2019 Jun 12];40(110):64-80. doi: 10.1590/0103-1104201611005 
28. Cruz ILC, Parente AS, Mesquita FOS, Jerônimo AS. Satisfação dos usuários com os serviços do Sistema Único de Saúde - SUS em um município do sertão de Pernambuco. Rev Multid Psic [Internet]. 2017 [cited 2019 Dec 20];12(39):142-63. Available from: https://idonline. emnuvens.com.br/id/article/view/984 